\title{
CAMBRIAN-ORDOVICIAN BOUNDARY BEDS AT MÄEKALDA, TALLINN, NORTH ESTONIA
}

The Mäekalda section, named by the street in the eastern margin of the Kadriorg Park, Tallinn, is exposed in a fresh roadcut for the construction of a new motorway since 1986. The section of Lower Palaeozoic rocks, from the siltstones of the Lower Cambrian Tiskre Formation to the Middle Ordovician Lasnamägi Stage was introduced to the majority of the Ordovician researchers of Baltoscandia during the WOGOGOB field excursion on July 14,1988 . The authors of the present paper introduce the results of the mineralogical and palaeontological (conodont, acritarch and brachiopod) studies of the Cambrian-Ordovician boundary beds represented by the Ulgase and Kallavere Formations (Fig. 1).

\section{The Olgase Formation}

The Upper Cambrian Ulgase Formation (thickness $3.20 \mathrm{~m}$ ) covers the underlying greenish grey argillaceous siltstones of the Lower Cambrian Tiskre Formation (Table 1) containing the lenses of light grey coarsegrained siltstones.

The lower boundary of the Ulgase Formation is sharp, marked by the colour change and the appearance of the phosphatic pebbles and debris of inarticulate brachiopods. The upper surface of the Tiskre Formation is dissected by up to $20 \mathrm{~cm}$ deep pockets and up to $5 \mathrm{~mm}$ wide vertical burrows, filled with sandy material containing debris of inarticulate brachiopods and small flat phosphatized pebbles. The base of the Olgase Formation contains in some places lenses of conglomerates up to $2 \mathrm{~m}$ in diameter with the thickness reaching $10 \mathrm{~cm}$, mostly depending on the pebble size. The conglomerates contain more than 50 per cent of pebbles of various size, cemented with clay-silty matrix. The source rocks of the pebbles have been of sedimentary origin, most frequently coarse-grained siltstones and fine-grained sandstones, some of them yielding valves of inarticulates.

Except the lenses of conglomerates at the base, the rocks of the Olgase Formation lack gravel material, consisting mainly of sandy siltstones with minor amounts of clay particles. The pelitic fraction exceeds 5 per cent only in the intercalations of argillaceous rocks and near the boundaries of the formation. By the rock types and structures, the section of the Ulgase Formation can be divided into four beds, starting from below.

Bed 1. Light-grey coarse-grained siltstones, intercalated by grey clays or argillaceous siltstones. The coarse-grained siltstones prevail, forming up to $30 \mathrm{~cm}$ thick layers which cover 70 per cent of the interval. The structure of this interval is generally horizontally-bedded, in places lenticular. The bedding plains of siltstones are surfaced with submillimeter clay rinds and contain brachiopod valves in higher concentrations. The uppermost $10 \mathrm{~cm}$ of this interval is represented by the thickest and most resistant layer of clay in this section. Thickness $1.20 \mathrm{~m}$.

Bed 2 is lithologically similar to Bed 1, differing from the latter in irregular stratifications of mosaic bedding of sand- and claystones: the mixed rock-types are not formed. Thickness $0.40 \mathrm{~m}$. 
Bed 3. Cross-bedded, coarse-grained and sandy siltstones. The bedding planes marked by clayey films and phosphatic brachiopod fragments. Thickness $1.00 \mathrm{~m}$.

Bed 4. Fine-grained sandstones and coarse-grained siltstones containing sparse pelitic material and thin clayey films on bedding planes, where the best preserved valves of phosphatic inarticulate brachiopods Ungula inornata and Oepikites sp., and the fragments of the problematic Torellella sp. occur. Thickness $0.60 \mathrm{~m}$.

\section{The Kallavere Formation}

The overlying Kallavere Formation is divided into the Maardu (lower) and Suurjōgi (upper) Members, based on the lithological features, such as grain size, structure, distribution and roundness of brachiopod fragments (Хейнсалу, 1987).

\section{The Maardu Member}

The Maardu Member has a lower boundary, distinctly marked by various petrological characteristics. Most frequently, the base of the Maardu Member begins with up to $0.20 \mathrm{~m}$ thick brachiopod coquina (the so-called Obolus conglomerate), containing densely packed valves of Ungula ingrica. In some places the lower boundary is marked by a thin layer of kerogenous argillite, or lenses of unsorted sandstone, containing phosphatic valves and debris of inarticulate brachiopods.

Table 1

Content of debris and grain size of terrigenous clastic material

\begin{tabular}{|c|c|c|c|c|c|c|c|}
\hline \multirow[b]{2}{*}{ Sample } & \multirow[b]{2}{*}{ Formation } & \multirow{2}{*}{$\begin{array}{c}\text { Content } \\
\text { of debris, } \\
\%\end{array}$} & \multicolumn{4}{|c|}{ Grain size, $\%$} & \multirow{2}{*}{$\begin{array}{c}\text { Total, } \% \\
>0.05 \\
\mathrm{~mm}\end{array}$} \\
\hline & & & $>1 \mathrm{~mm}$ & $\begin{array}{c}1.0-0.1 \\
\mathrm{~mm}\end{array}$ & $\begin{array}{c}0.1-0.01 \\
\mathrm{~mm}\end{array}$ & $\underset{\mathrm{mm}}{<0.01}$ & \\
\hline $\begin{array}{l}\text { Mä-86-20 } \\
\text { Mä-86-19 } \\
\text { Mä-86-18 } \\
\text { Mä-86-17 } \\
\text { Mä-86-16 } \\
\text { Mä-86-15 } \\
\text { Mä-86-14 } \\
\text { Mä-86-13 } \\
\text { Mä-86-12 } \\
\text { Mä-86-11 } \\
\text { Mä-86-10 } \\
\text { Mă-86-9 } \\
\text { Mä-86-8 } \\
\text { Mä-86-7 } \\
\text { Mä-86-6 } \\
\text { Mä-86-5 } \\
\text { Mä-86-4 } \\
\text { Mä--86-3 } \\
\text { Mä-86-2** } \\
\text { Mä-86-2A** } \\
\text { Mä-86-1 }\end{array}$ & $\begin{array}{l}\text { Kallavere } \\
\text { Kallavere } \\
\text { Kallavere } \\
\text { Kallavere } \\
\text { Kallavere } \\
\text { Kallavere } \\
\text { Kallavere } \\
\text { Kallavere } \\
\text { Olgase } \\
\text { Olgase } \\
\text { Olgase } \\
\text { Olgase } \\
\text { Olgase } \\
\text { Olgase } \\
\text { Olgase } \\
\text { Olgase } \\
\text { Olgase } \\
\text { Olgase } \\
\text { Olgase } \\
\text { Olgase } \\
\text { Tiskre }\end{array}$ & $\begin{array}{r}28.7 \\
34.7 \\
9.9 \\
10.1 \\
6.0 \\
16.6 \\
12.1 \\
32.5 \\
8.1 \\
9.4 \\
16.9 \\
6.3 \\
9.3 \\
1.5 \\
9.5 \\
3.3 \\
5.7 \\
1.1 \\
0.7 \\
\text { n.d. } \\
-\end{array}$ & $\begin{array}{c}0.4 \\
0.3 \\
\overline{-} \\
\overline{-} \\
\overline{\bar{E}} \\
34.5^{*} \\
\overline{-} \\
\overline{-} \\
\overline{-} \\
\overline{-} \\
\overline{-} \\
\overline{-} \\
58.0^{*} \\
\overline{-}\end{array}$ & $\begin{array}{r}95.3 \\
96.3 \\
89.6 \\
83.0 \\
43.0 \\
54.5 \\
16.7 \\
37.9 \\
50.9 \\
28.9 \\
28.7 \\
37.0 \\
0.6 \\
16.5 \\
14.1 \\
12.9 \\
21.9 \\
13.4 \\
6.4 \\
5.7\end{array}$ & $\begin{array}{r}1.9 \\
1.2 \\
9.0 \\
17.0 \\
50.2 \\
43.6 \\
83.2 \\
37.7 \\
27.5 \\
42.0 \\
65.1 \\
67.2 \\
60.0 \\
21.8 \\
83.4 \\
43.0 \\
82.8 \\
74.1 \\
60.0 \\
24.0 \\
58.3\end{array}$ & $\begin{array}{r}2.4 \\
2.2 \\
1.4 \\
6.8 \\
1.9 \\
16.8 \\
11.1 \\
34.6 \\
7.1 \\
6.0 \\
4.1 \\
30.0 \\
77.6 \\
0.1 \\
42.9 \\
4.3 \\
4.0 \\
26.6 \\
11.6 \\
36.0\end{array}$ & $\begin{array}{r}96.8 \\
97.5 \\
94.6 \\
99.2 \\
91.5 \\
98.0 \\
79.0 \\
85.7 \\
64.4 \\
88.6 \\
93.2 \\
94.8 \\
95.8 \\
0.6 \\
96.5 \\
53.5 \\
94.5 \\
95.2 \\
68.2 \\
81.4 \\
28.8\end{array}$ \\
\hline
\end{tabular}

\footnotetext{
* Including 28.7 and 52 per cent coarse clasts Mä-86-13 and Mä-86-2A, respectively. ** Sample Mä-86-2 is taken from the base of the Olgase Formation without coarse clasts and $M a ̈-86-2 \mathrm{~A}$ from the lense of conglomerate,
} 
The light-yellow quartzose sandstones and siltstones of the Maardu Member contain numerous thin intercalations or films of dark-brown kerogenous argillites (the so-called Dictyonema shales). The thickness of these intercalations varies from some millimetres to $10 \mathrm{~cm}$ and they form less than 10 per cent of total thickness of the Maardu Member.

The grain size of the sandstones and siltstones of the Maardu Member increases upwards: in the lower part, silt particles prevail or occur in the equal concentrations with sand grains which explicitly prevail in the upper part of the member (Table 1). The content of the pelitic particles, represented mostly by the fraction $0.01-0.02 \mathrm{~mm}$ is minute, except some argillaceous intercalations with higher pelite content.

Macrofossils are represented by a phosphatic inarticulate brachiopod Ungula ingrica and a graptolite Rhabdinopora ex. gr. flabelliformis, found in an argillite interbed, $30 \mathrm{~cm}$ below the upper boundary of the Maardu Member. The total thickness of the Maardu Member is $1.5 \mathrm{~m}$.

\section{The Suurjõgi Member}

Because of the stairlike roadcut, the upper part of the Kallavere Formation - the Suurjōgi Member is only partly exposed at Mäekalda. Therefore, apart from the description of this section, the Suurjõgi Member was sampled and studied in the Hundikuristik section $1 \mathrm{~km}$ northwards.

The lower boundary of the Suurjōgi Member is distinct: light grey finegrained horizontally-bedded sandstones of the Maardu Member are covered by brownish-grey cross-bedded fine- to medium-grained sandstones, containing rounded brachiopod debris in remarkable concentrations. The cross-bedding is expressed in the alternation of the layers with different debris content. In the lower part of the Suurjõgi Member, about $1 \mathrm{~cm}$ thick sharply angular pieces of kerogenous argillite occur. They are most typical of the Hundikuristik and, to a lesser extent, in the Mäekalda section. In both sections, the uppermost, $4-10 \mathrm{~cm}$ thick layer is cemented with pyrite, forming the so-called pyrite layer. The thickness of the Suurjōgi Member, both in the Hundikuristik and Mäekalda sections, is $0.90 \mathrm{~m}$.

The upper boundary is distinct: the sandstones of the Suurjōgi Member are covered by the dark-brown kerogenous argillites ( Dictyonema shales») of the Türisalu Formation.

The textural (Table 1) and mineral features (Table 2) of the rocks have been studied throughout the whole terrigenous part of the section, except the interlayers of kerogenous argillites.

The both boundary units (the Ulgase and Kallavere Formations) are similar: (1) in high mineralogical maturity expressed by prevalence of quartz in the group of light minerals as well as by zircon-tourmalinerutile association in the group of nonopaque allothigenous heavy minerals; (2) in features of the authigenic mineralization from which especially typical are secondary overgrowths and phosphatic pellicles on some detrital minerals, despite that they differ by intensity in the vertical range. Thus secondary overgrowths on detrital feldspar grains are more common in the deposits of the Kallavere Formation, especially in the rocks of the Suurjögi Member, whereas the Ulgase ones have less than 5 per cent of grains with limped overgrowths. Phosphatic pellicles on detrital minerals (commonly on quartz, zircon, ilmenite and rutile) are more typical of the deposits of the Kallavere Formation yielding always more than 10 per cent of this kind of grains.

In addition, all the lithostratigraphical units have some special characteristics in the texture and in the group of nonopaque allothigenous heavy minerals; 


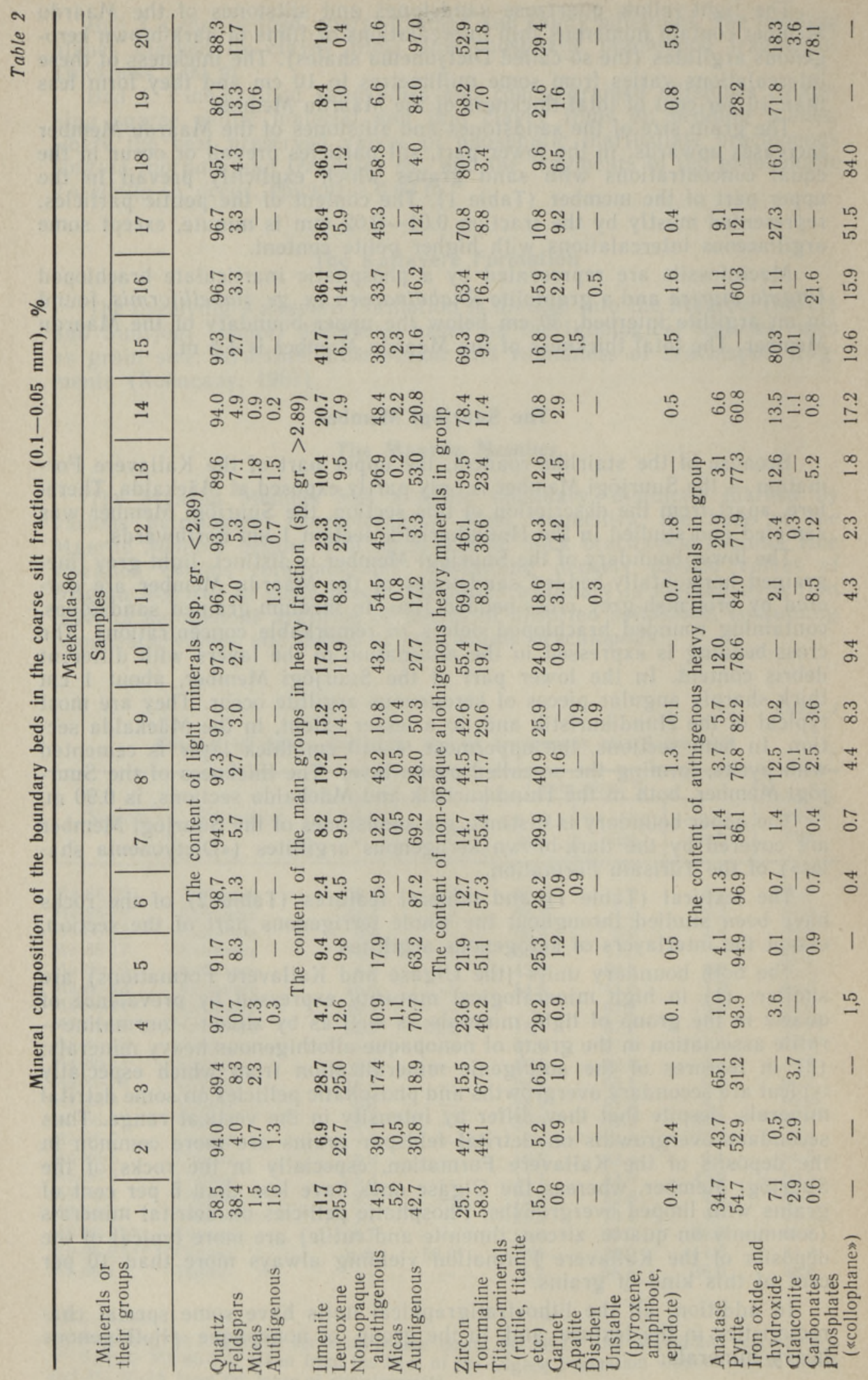


(1) the Olgase and Maardu rocks are moderately sorted whereas the Suurjōgi ones are well sorted;

(2) the allothigenous grains of the Ulgase silt- and sandstones are subrounded and rounded as the grains of the Kallavere Formation are well-rounded and (seldom) rounded;

(3) in the triplet zircon-tourmaline-rutile of the Kallavere Formation the former prevail always whereas in the rocks of the Ulgase Formation tourmaline has prevalence, particularly in its lower part (up to sample 8).

Thus, the lithostratigraphical units (the Ulgase Formation, the Maardu and Suurjõgi Members) can be recognized on the basis of the textural and mineral characteristics of their rocks. Additionally, twofold subdivision on the ground of the mineralogical composition of the Ulgase Formation is turned to be more important, than it has been known previously (Менс, 1984).

Acritarchs. From the ten samples studied on acritarchs (Fig. 1), the lower three taken from the Tiskre Formation are barren. The samples from the Ulgase and Kallavere Formations contained quite well-preserved acritarchs in different quantities. By taxonomic composition two acritarch assemblages can be distinguished, one representing the Ulgase Formation, and the other - the lowermost Maardu Member.

The acritarch assemblage of the Ulgase Formation is rich both in the number of specimens and species diversity; the highest number of species was observed in samples A-0493 and A-0495. This assemblage contains mostly new species of the genera Timofeevia, Stelliferidium, Cymatiogalea, Impluviculus, Leiofusa, Cristallinium, Vulcanisphaera and Veryhachium. The formerly described forms Stelliferidium cortinulum (Deunff), Deunff Gorka et Raischer, ? S. glabva Martin, Vulcanisphaera turbata Martin, Leiofusa stoumonensis Vang., Cristallinium cambriense (Slavikova) Vang., C. randomense Martin and Veryhachium dumontii Vang. have been reported on Upper Cambrian sections in some places (Martin, Dean, 1981; Vanguestaine, 1973). The acritarch assemblage of the Ulgase Formation of the Mäekalda section is similar to the assemblages observed in the Ulgase, Turjekelder and Suhkrumägi sections and can be correlated to the Olenus Zone (Волкова, 1982; Волкова, Менс, 1988).

The acritarch assemblage of the lowermost part of the Maardu Member differs from that of the Ulgase Member in an abrupt disappearance of most species of the genera Timofeevia, Cristallinium, Vulcanisphaera, Leiofusa, Veryhachium and Impluviculus, and the appearance of diacrodiids, among which Acanthodiacrodium angustum (Downie) Combaz, A. comptulum Rasul and Dasydiachrodium ornatum Combaz are known only from the Tremadocian rocks (Martin, 1982; Rasul, 1979; Волкова, Менс, 1988). Among the transient genera, mostly new species appear: $S$. aff. fimbria, C. cuvillieri (Deunff) Deunff and C. cristata (Downie).

Conodonts were studied from twenty one samples through the section of the Ulgase and Kallavere Formations (Fig. 1). Conodonts are extremely rare in the Ulgase Formation except sample 6 containing Phakelodus tenuis, and sample 10 with two specimens of ?Proconodontus. Samples 1320 from the sandstones of the Kallavere Formation contained numerous conodonts, prevailingly species of the genus Cordylodus (Fig. 2).

Samples 13 and 14 from the base of the Maardu Member contained few poorly preserved specimens of Cordylodus proavus, represented mostly by alpha morph and also by specimens with the typical outline and a high basal cavity, but having secondary tips (Viira et al., 1987).

In sample 15, and upwards, the genus Cordylodus is represented by an increasing number of specimens, and by higher variability and diversity of species. By the shape of basal cavity two types of Cordylodus rounded 


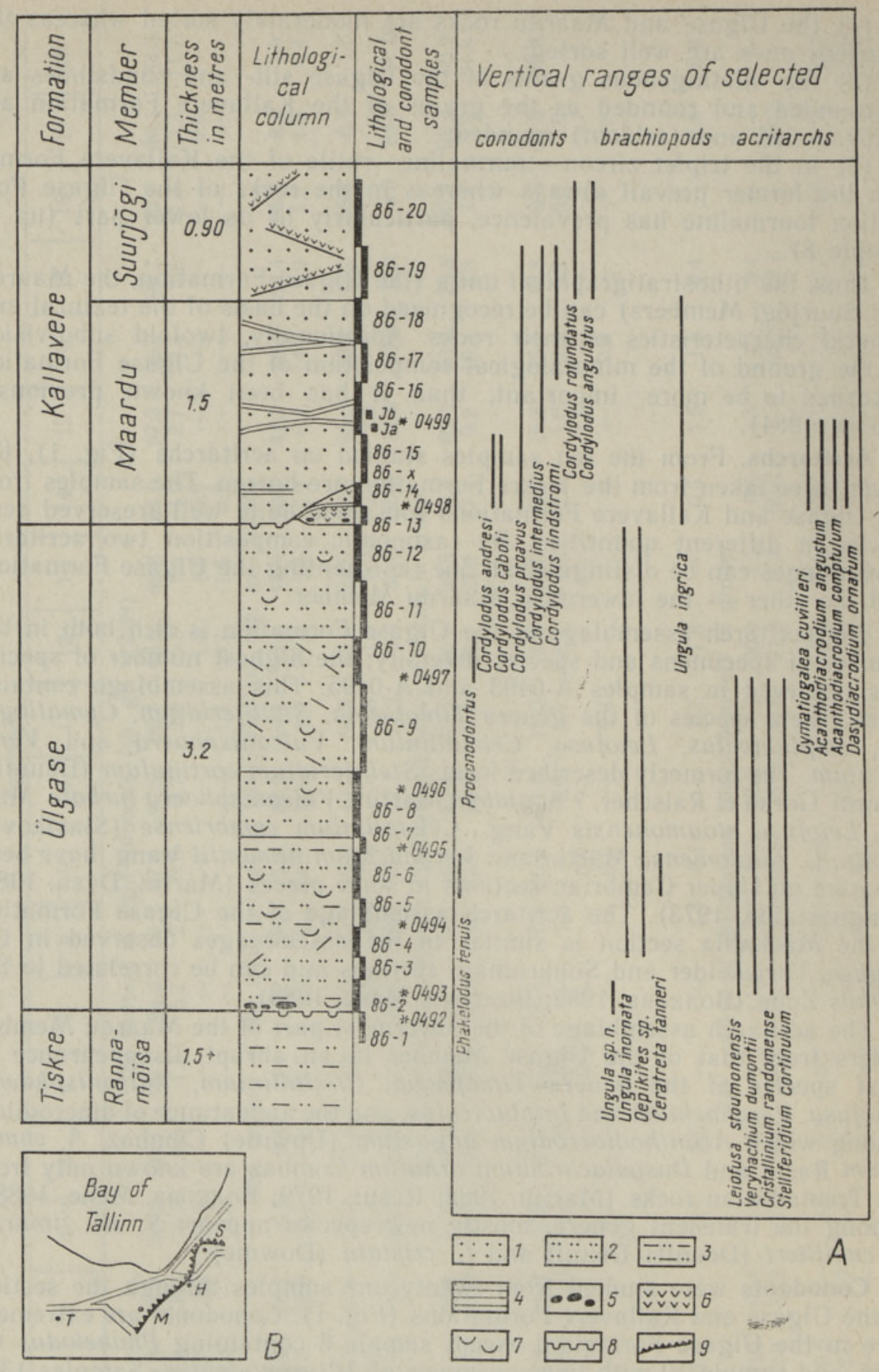

Fig. 1. A. The Mäekalda section of the Cambrian-Ordovician boundary beds. In the graph of samples the asterisk indicates the location of acritarch samples. B. Location of stratigraphic sections discussed in the text: T - Tõnismägi, $M-$ Mäekalda, $\mathrm{H}-$ Hundikuristik, S - Suhkrumägi. Legend: 1 - sandstone, $2-$ siltstone, $3-$ argillaceous rock, 4 - kerogenous argillite («Dictyonema shale»), 5 - phosphatic pebbles, 6 - brachiopod coquina («Obolus conglomerate»), 7 - valves and detritus of inarticulate brachiopods, 8 - discontinuity surface, 9 - clint.

Fig. 2. Rounded specimens of Cordylodus from samples $86-14,86-15$ and $86-17$ of Mäekalda section. 


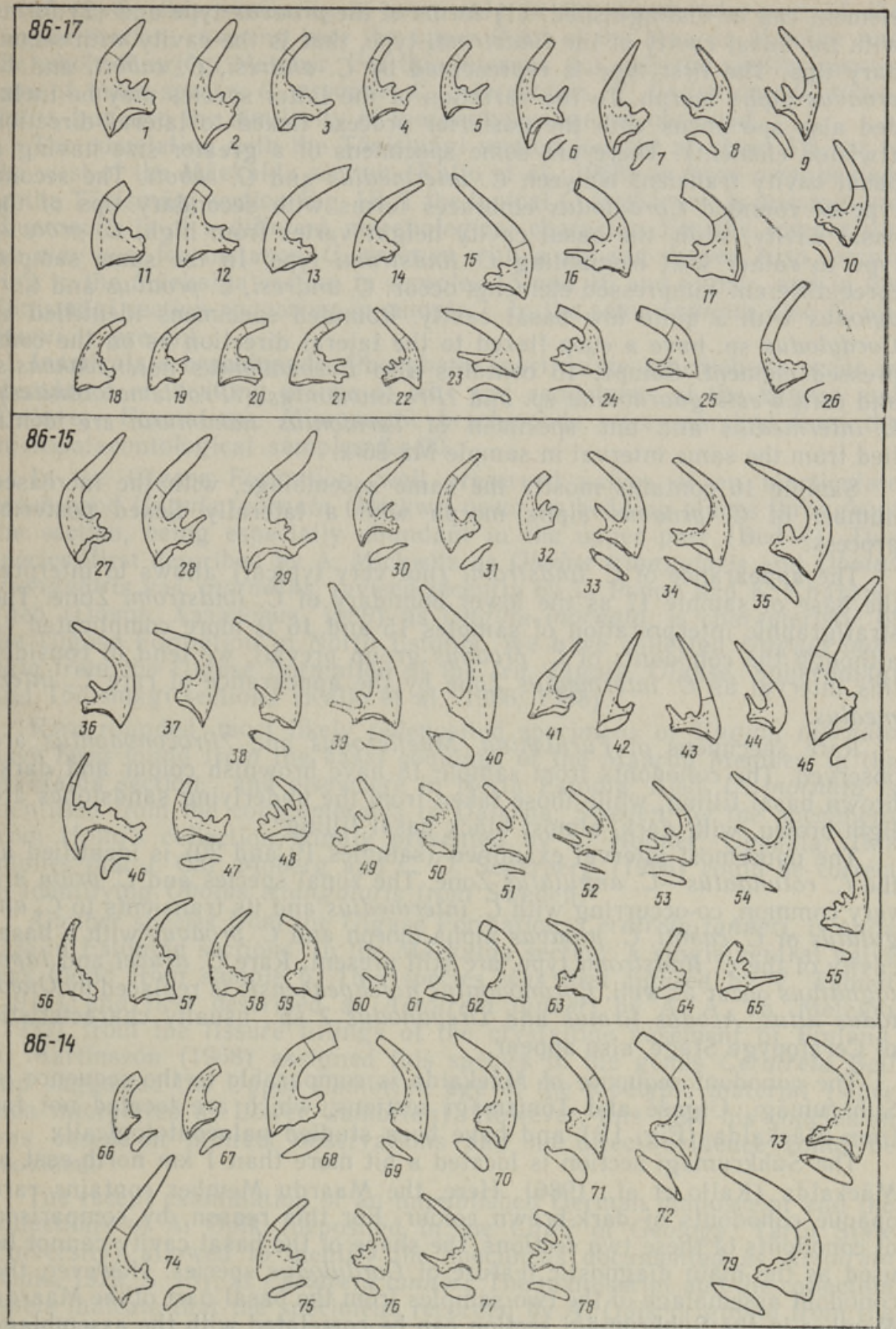

1-10. Cordylodus lindstromi Druce et Jones, specimens Cn1230-Cn1239, 11-17, 26. Cordylodus intermedius Furnish, Cn1240-Cn1247. Some specimens with basal cavity transitional to $C$. caboti or C. angulatus. 18-22, 46-55, 75-78. Cordylodus proavus Müller alpha morph, Cn1248-Cn1267. 23-25. Cordylodus aff. drucei Miller, Cn1268Cn1270. 27-40, 66-74. Cordylodus proavus Müller with basal cavity of lindstromi-type, Cn1271-Cn1293. 41-44. Cordylodus sp., Cn1294-Cn1297. 45, 79. Cordylodus intermedius Furnish with basal cavity of caboti-type, Cn1298, Cn1299. 56-59. Cordylodus andresi Viira et Sergeyeva, Cn1300-Cn1303. 60-63. Cordylodus primitivus Bagnoli, Barnes et Stevens, Cn1304-Cn1307. 64, 65. Cordylodus caboti Bagnoli, Barnes et Stevens, Cn1308, Cn1309. 
element can be distinguished: (1) forms of the proavus type and (2) forms with the basal cavity of the lindstromi type, that is the cavity with secondary tips. The first type is represented by $C$. andresi, $C$. caboti, and $C$. proavus alpha morph. To the variation of the latter species may be included also specimens with the posterior process flexed to lateral direction (twisted element). There are some specimens of a greater size having a basal cavity transient between $C$. intermedius and $C$. caboti. The second type of rounded Cordylodus embraces forms with secondary tips of the basal cavity, while the basal cavity height varies from high, $C$. proavus type to rather low, resembling $C$. lindstromi type. In the same sample, three different compressed elements occur: C. andresi, C. proavus and Cor-

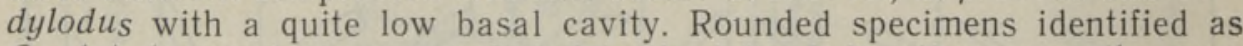
Cordylodus sp. have a cusp flexed to the lateral direction as on the compressed element. Sample 15 contains also Eoconodontus notchpeakensis, and rare Westergaardodina sp. and ?Proconodontus (?Problematoconites). C. intermedius and one specimen of Teridontus nakamurai are identified from the same interval in sample Mä-86-x.

Sample 16 contains mostly the same assemblage, with the increased number of $C$. proavus alpha morph with a laterally flexed posterior process.

The appearance of $C$. lindstromi (not very typical) allows to interpret the base of sample 17 as the lower boundary of $C$. lindstromi Zone. The stratigraphic interpretation of samples 15 and 16 is more complicated although the conodonts of $C$. proavus group prevail, we tend to consider this interval as $C$. intermedius Zone by the appearance of rare $C$. intermedius.

Rare specimens of Furnishina, Muellerodus and ?Proconodontus are observed. The conodonts from sample 18 have brownish colour and darkbrown basal filling, while those taken from the underlying sandstones are light-brown, with dark, almost black basal filling.

The uppermost interval examined (samples 19 and 20) is identified as the $C$. rotundatus $-C$. angulatus Zone. The zonal species and $C$. prion are very common, co-occurring with $C$. intermedius and its transients to $C$. angulatus or $C$. caboti. $C$. proavus alpha morph and $C$. proavus with a basal cavity of the $C$. lindstromi type, are still present. Rare $C$. drucei and Iapetognathus occur as well. Eoconodontus notchpeakensis is replaced by Oneotodus altus. Acodus firmus and Drepanodus ? sp., usually characteristic of Ceratopyge Stage, also appear.

The conodont sequence of Mäekalda is comparable to the sequence in Suhkrumägi, Ulgase and Tōnismägi sections, which are located not far from Mäekalda (Fig. 1B) and have been studied palaeontologically.

The Suhkrumägi section is located a bit more than $1 \mathrm{~km}$ north-east of Mäekalda (Kaljo et al., 1986). Here, the Maardu Member contains rare opaque conodonts of dark-brown colour. For this reason, by comparison of conodonts of these two sections, the shape of the basal cavity cannot be used as the main diagnostic feature of Cordylodus species. However, the conodont assemblage of the two samples from the basal part of the Maardu Member in the Suhkrumägi section can be correlated with the assemblage in samples 13-16 of the Mäekalda section. The occurrence of Teridontus nakamurai at this level in both sections is important. In other regions of the world, this species is rather common in the interval $C$. proavus Zone Fauna F (Miller, 1980), but in the East Baltic T. nakamurai is known only from these two sections. The Suurjōgi Member is in both sections characterized by the conodonts of the $C$. rotundatus $-C$. angulatus Zone.

The conodont sequence in the Ulgase section, located at about $15 \mathrm{~km}$ east of Mäekalda, seems to be most similar to that of the Mäekalda section (Хейнсалу et al., 1987). 
However, this similarity is seen only in the Cordylodus-part of the Olgase section, covering here the upper third of the Maardu Member and the whole Suurjõgi Member. For this interval, not only the similar succession of index-species C. proavus, C. intermedius, C. lindstromi, C. rotundatus, but also the similarity of morphotypes can be observed.

The correlation with the Tõnismägi section located at about $1.5 \mathrm{~km}$ to the west of the Mäekalda section (Kaljo et al., 1988) is more complicated. In the Tõnismägi section Fig. 1B, T the typical C. lindstromi is missing and C. proavus is of a different morphological character. For the comparison we may use, for instance, $C$. proavus with a zig-zag-shaped cusp, occurring in the Mäekalda section in samples 15 and 16 and higher, and in the Tõnismägi section appearing in sample 7 . In the same samples also $C$. aff. drucei is present.

Inarticulate brachiopods. Phosphatic inarticulate brachiopods occur in abundance on bedding planes of silt- and sandstones of the Ulgase and Kallavere Formations. Microscopic brachiopods were searched from the micropalaeontological samples 2-20.

In the Ulgase Formation, well preserved valves of an inarticulate brachiopod Ungula inornata (Mickw.) occur on bedding planes throughout the section, being especially abundant in the upper part (Bed 4). This species, first described by A. Mickwitz as Obolus triangularis and Obolus triangularis var. inornatus, revised recently by L. Popov and K. Khazanovitch (Попов, Хазанович, 1989) as Ungula inornata, is characteristic of the Ulgase Formation in North Estonia. We have collected Ungula inornata from the Ulgase Formation of the Iru, Jägala, Ulgase, Suhkrumägi and Tõnismägi sections (Kaljo et al., 1986, 1988).

Rare rounded, most likely redeposited specimens of Ungula inornata have been found from the basal coquinas of the Maardu Member, in the Mäekalda section, and elsewhere in North Estonia. Also, U. inornata is identified from the conglomerates of Dalarna, Sweden, by the specimens from Holm's collection, kindly presented by L. Holmer, Uppsala. This implies that J. Chr. Moberg and C. O. Segerberg (1906) could be correct in identifying Obolus triangularis from Sweden.

Another species from the Olgase Formation, Ceratreta tanneri, is quite rare in Estonian sections. In the Mäekalda section, a single ventral valve was found from sample 6 . This species was first figured by V. Tanner (1911) and first described as Acrotreta tanneri by A. A. Th. Metzger (1922) from the fissure fillings of the crystalline basement of Finland. A. Martinsson (1968) assigned this species to the genus Ceratreta Bell and suggested the Upper Cambrian age of the topotypic material (since then interpreted as Lower Cambrian). However, this time his conclusion was based on indirect observations and no direct evidence could be provided.

The recent examination of an unpublished German manuscript and the collections of A. Opik (deposited in the Chair of Geology, Tartu State University) allowed to identify the specimens documented as Acrotreta (Öpik, 1929, S. 13), as Ceratreta tanneri. The manuscript and the collection labels indicate that the specimens recorded by A. Opik originate from the temporary excavation near the Hundikuristik section, i. e. only $1 \mathrm{~km}$ north of the present Mäekalda roadcut, where the siltstones of the Ulgase Formation were exposed in 1930s.

L. Popov reporis Ceratreta tanneri from the base of the Ladoga Formation in Syas River (Kaljo et al., 1986, Fig. 3) and from the Ulgase Formation of some sections in North Estonia (pers. comm.). During the WOGOGOB meeting in July 1988, L. Holmer (pers. comm.) provided interesting data about the Västanå section near Borensberg, Sweden, where Ceratreta tanneri is found in association with Phakelodus tenuis, Wester- 
gaardodina, and other Upper Cambrian conodonts from the interval with Peltura scarabeoides (Bed 3 in Westergård, 1922, Fig. 17), while the overlying beds contain Cordylodus proavus and, upwards, Rhabdinopora flabelliformis. At the same time, sample 6 from Mäekalda, is referred to the Olenus Zone by acritarch correlation. Thus, by this quite incomplete evidence Ceratreta tanneri occurs in the Upper Cambrian, ranging from the Olenus to the Peltura scarabeoides Zone.

Rare specimens of Oepikites sp., found on bedding planes, wcre too poorly preserved for specific identifications. However, L. Popov (pers. comm.) has reported Oepikites fragilis from the Ulgase Formation of the Mäekalda section.

The pebbles at the base of the Ulgase Formation contain the fragments of an unidentifiable obolid species. Similar fragments have been recorded from the base of the Ulgase Formation of the Ulgase and Jägala sections. A single, almost complete brachial valve found in the Jägala section represents a new species, probably of the Middle Cambrian origin.

The basal coquina of the Maardu Member consists almost exclusively of the valves of Ungula ingrica (Eichwald). This species was first described by E. Eichwald (1829, S. 274) and later mixed up with Obolus apollinis (Eichw.) by A. Mickwitz (1896). The comprehensive explanation of this mix-up is given elsewhere (see Хейнсалу и др., 1987, 161-163).

It is noticeable that the coquina does not contain the valves of Schmidtites celatus (Vern.), usually present in «Obolus conglomerate». Such a monospecific accumulation of thick Ungula valves may indicate facial distribution of brachiopods and/or hydrodynamic conditions of the basin. In the upper part of the Maardu Member, the specimens of Ungula ingrica are sparsely distributed. L. Holmer (pers. comm.) has provided the latex casts of the brachiopods from 12 Swedish localities, identified as Ungula ingrica. In Sweden, Ungula ingrica occurs in the basal conglomerates of the lowermost Ordovician.

The sandstones of the Suurjoggi Member contain rounded brachiopod shell fragments and debris of phosphatic inarticulates, mostly unidentifiable in species level. The rock structure and the roundness of the brachiopod shell fragments indicate significant redeposition of the bioclastic material in hydrodynamically active environment. Therefore, some rare identifications of poorly preserved Ungula ingrica and Schmidtites celatus are of a low stratigraphic value.

Thus, the presence of disconformity within the studied boundary interval, makes the definition of the Cambrian-Ordovician boundary impossible. However, the Mäekalda section is an important sequence for the cooccurrence of acritarchs, conodonts and inarticulate brachiopods, adding valuable information to the correlation of terrigenous sections.

\section{REFERENCES}

Eichwald, E. Zooloogia specialis. Pars prior. Vilnae, 1829.

$\checkmark$ Kaljo, D., Borovko, N., Heinsalu, H., Khazanovich, K., Mens, K., Popov, L., Sergeyeva, S., Sobolevskaya, R., Viira, V. The Cambrian-Ordovician boundary in the BalticLadoga clint area (North Estonia and Leningrad Region, USSR) // Proc. Acad. Sci. ESSR. Geol., 1986, 35, N 3, 97-108.

$\checkmark$ Kaljo, D., Heinsalu, H., Mens, K., Puura, I., Viira, V. Cambrian-Ordovician boundary beds at Tônismägi, Tallinn, North Estonia // Geol. Mag., 1988, 125, N 4, 457463.

Martin, F. Some aspects of Late Cambrian and Early Ordovician acritarchs // M. G. Bassett, W. T. Dean (eds). The Cambrian-Ordovician Boundary: Sections, Fossil Distributions and Correlations, Nat. Mus. Wales, Geol. Ser., 1982, N 3, 29-40.

Martin, F., Dean, W. T. Middle and Upper Cambrian and Lower Ordovician acritarchs from Random Island, eastern Newfoundland // Bull. Geol. Surv. Canada, 1981, N 343. 
Martinsson, A. Cambrian palaeontology of Fennoscandian basement fissures // Lethaia, $1968,1, \mathrm{~N} 2,137-155$.

Metzger, A. A. Th. Beiträge zur Paläontologie des nordbaltischen Silures im Ålandsgebiet // Bull. Comm. Géol. Finl., 1922, 56.

Mickwitz, A. Uber die Brachiopodengattung Obolus Eichwald // Mém. Acad. Sci. St. Pétersbourg, 1896, Sér. 8, 4, N 2.

Miller, J. F. Taxonomic revisions of some Upper Cambrian and Lower Ordovician conodonts with comments on their evolution // Univ. Kansas Paleontol. Contrib., 1980, 99

Moberg, J. Chr., Segerberg, C. O. Bidrag till känedomen om Ceratopygeregionen med särskild hänsyn till dess utveckling i Fogelsångstrakten. Lund, 1906. Meddelande från Lunds Geologiska Fältklubb, Ser. B, N 2.

Opik, A. Der Estländische Obolenphosphorit. Tallinn, 1929.

Razul, S. M. Acritarch Zonation of the Tremadoc Series of the Schneton Shales, Wrekin, Shropshire, England // Palynology, 1979, 3, 53-72.

Tanner, $V$. Uber eine Gangformation von fossilienführenden Sandstein auf der Halbinsel Långbergsöda-Öjen im Kirchspiel Saltvik, Âland-Inseln // Bull. Comm. Géol. Finl., 1911, 25.

Vanguestaine, $M$. New acritarchs from the Upper Cambrian of Belgium // Microfossils of the Oldest Deposits. Proc. 3rd Int. Palynol. Conf. Moscow, 1973, 28-30.

Westergård, A. H. Sveriges Olenidskiffer // Sveriges Geologiska Undersökning, 1922, Ser. $\mathrm{Ga}, \mathrm{N} 18$.

Viira, V., Sergeyeva, S., Popov, L. Earliest representatives of the genus Cordylodus (Conodonta) from Cambro-Ordovician boundary beds of North Estonia and Leningrad Region // Proc. Acad. Sci. ESSR. Geol., 1987, 36, N 4, 145--153.

Волкова Н. А. О возрасте юлгазеской пачки на граннце кембрия и ордовика в Эстонии // Сов. геол., 1982, № 9, 85-88.

Волкова Н., Менс K. Распределение акритарх в пограничных слоях кембрия и ордовика разреза Сухкрумяги (Северная Эстония) // Изв. АН ЭССР. Геол., 1988, 36, № 3, 97-102.

Менс $K$. Минералогическая характеристика юлгазеских отложений окрестности Маарду // Изв. АН ЭССР. Геол., 1984, 33, № 3/4, 96-103.

Попов Л. Е., Хазанович К. К. Лингулаты (беззамковые брахиоподы с фосфатнокальциевой раковиной) // Опорные разрезы и стратиграфия кембро-ордовикской фосфоритоносной оболовой толщи на северо-западе Русской платформы. Л., 1989.

Хейнсалу $X$. Литостратиграфическое расчленение тремадокских отложений Северной Эстонии // Изв. АН ЭССР. Геол., 1987, 36, № 2, 66-78.

Хейнсалу Х., Вийра В., Менс К., Оя Т., Пуура И. Кембрийско-ордовикские пограничные отложения разреза Юлгазе, Северная Эстония // Изв. АН ЭССР. Геол., 1987, 36, № 4, 154-165.

Academy of Sciences of the Estonian SSR, Institute of Geology

Received

March 27, 1989

Tartu State University

Kaisa MENS, Viive VIIRA, I. PAALITS, I. PUURA

\title{
KAMBRIUMI JA ORDOVIITSIUMI PIIRIKIHID MÄEKÁLDA LÄBILOOIKES (TALLINN)
}

Kiirtrammitee rajamisel tekkinud Mäekalda läbilōike alumises, terrigeenses osas paljanduvad liivakihid, aleuroliidid ja savid kuuluvad Tiskre, Olgase ning Kallavere kihistusse. On esitatud nende settekehade mineraloogilise ja paleontoloogilise (akritarhide, konodontide, lukuta brahhiopoodide) uurimise tulemused.

\author{
Кайса МЕНС, Вийве ВИИРА, И. ПААЛИТС, И. ПУУРА
}

\section{КЕМБРИИСКО-ОРДОВИКСКИЕ ПОГРАНИЧНЫЕ ОТЛОЖЕНИЯ РАЗРЕЗА МЯЭКАЛДА (ТАЛЛИНН)}

Дана минералогическая и палеонтологическая (акритархи, конодонты, беззамковые брахноподы) характеристика нижней - терригенной части разреза Мяэкалда, начиная с алевролитов тискреской свиты нижнего кембрия и завершая разнозернистыми песчаниками суурйыгиской пачки каллавереской свиты нижнего ордовика. 